\title{
Do older adults benefit from Pilates-based exercises? The application of Pilates as a geronto-prophylaxis - Indications, methodology and training effects
}

Czy seniorzy mogą czerpać korzyści z ćwiczeń metodą Pilatesa? Zastosowanie metody Pilatesa w gerontoprofilaktyce: wskazania, metodologia i efektywność

\author{
Małgorzata Eliks ${ }^{1 * B-D, F} \oplus$, Krystyna Zeńczak-Praga ${ }^{1 *, A-D \oplus}$,

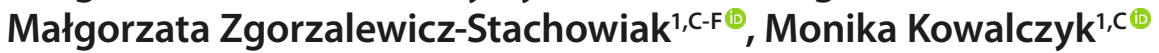 \\ ${ }^{1}$ K. Marcinkowski Medical University, Poznan, Poland \\ A - Koncepcja i projekt badania, B - Gromadzenie i/lub zestawianie danych, C - Analiza i interpretacja danych, \\ $D$ - Napisanie artykułu, E - Krytyczne zrecenzowanie artykułu, F - Zatwierdzenie ostatecznej wersji artykułu \\ * równorzędne pierwsze autorstwo
}

Eliks M, Zeńczak-Praga K, Zgorzalewicz-Stachowiak M, Kowalczyk M. Do older adults benefit from Pilates-based exercises? The application of Pilates as a geronto-prophylaxis - Indications, methodology and training effects. Med Og Nauk Zdr. 2019; 25(4): 208-212. doi: 10.26444/ monz/114241

\section{Abstract}

Introduction. Physical activity is essential for seniors as it might improve quality of life and influence the physical and mental states. One of the serious physical disturbances in older adults concerns balance disorders and falls. Pilates is a method of exercises influencing the control of posture, and according to many authors is safe training recommended for seniors.

Objective. The aim of this study is to assess the current state of knowledge related to Pilates used by older adults, and to assess the actual trend with seniors in mind. Focus is directed especially on latest publications on the effectiveness of Pilates performed by the elderly from the different aspects of human life. An attempt is made to standardize the of application of Pilates in seniors.

Results. According to reviews, Pilates is effective in improving static and dynamic balance in older adults, that might influence the reduction of the risk of falls. Improvement was observed in Pilates groups in comparison to no intervention, and other forms of training. It was found that Pilates training also improved lower limb strength, hip and lower back flexibility, and cardiovascular endurance. A new trend was observed in the beneficial effects of Pilates exercises on the mental health of older adults.

Conclusions. Due to the increasing need for maintaining optimal functioning in seniors, it is crucial to find a proper physical activity to apply in geronto-prophylaxis. Pilates influences beneficially on, i.a., balance and strengthening of muscles, as well as mental health. It can therefore be utilised in geronto-prophylaxis. In most publications, this training was performed 2-3 times a week with a single session lasting 40-60 minutes. However, the time of intervention varied from 4-16 weeks.

\section{Key words}

Pilates based exercises, functional status, aged, geronto-prophylaxis

Address for correspondence: Monika Kowalczyk, K. Marcinkowski Medical University, Poznan, Poland

E-mail:monikakowalczyk@ump.edu.pl

Received: 10.09.2019; Accepted: 15.11.2019; first published: 10.12.2019

\section{Streszczenie}

Wprowadzenie i cel pracy. Aktywność ruchowa znacząco poprawia jakość życia seniorów poprzez wpływ na ich fizyczne i psychiczne funkcjonowanie. Jednymi z istotnych zagrożeń w tym wieku są zaburzenia równowagi oraz upadki. Metoda Pilatesa jest systemem ćwiczeń wpływającym na kontrolę postawy i może być bezpiecznie stosowana u seniorów. Celem pracy było przedstawienie literatury - przeglądów systematycznych oraz metaanaliz, a także najnowszych badań dotyczących zastosowania metody Pilatesa u osób starszych i analiza jej efektywności w różnych obszarach życia. Ponadto podjęto próbę standaryzacji stosowania tej metody u seniorów.

Skrócony opis stanu wiedzy. Zgodnie z wynikami badań metoda Pilatesa korzystnie wpływa na poprawę równowagi statycznej i dynamicznej, czego efektem może być zmniejszenie prawdopodobieństwa upadku. Ta istotna poprawa była obserwowana w badanej grupie w porównaniu do grup kontrolnych oraz do innych form aktywności fizycznej. Udowodniono także pozytywny wpływ ćwiczeń Pilatesa na poprawę siły mięśni kończyn dolnych, zakresu ruchomości odcinka lędźwiowego kręgosłupa oraz wydolności sercowo-naczyniowej. Nowym trendem było wykazanie, iż stosowanie tej metody także wpływa korzystnie na poprawę zdrowia psychicznego u osób starszych.

Podsumowanie. Ze względu na coraz większą potrzebę zachowania optymalnej sprawności fizycznej u osób starszych istnieje konieczność znalezienia form aktywności ruchowej, mających zastosowanie w gerontoprofilaktyce. Metoda Pilatesa poprzez korzystny wpływ m.in. na równowagę oraz wzmocnienie siły mięśniowej, a także poprawę funkcjonowania psychicznego wpisuje się pozytywnie w profilaktykę gerontologiczną. W większości badań, w których uzyskano pozytywny efekt, Pilates był stosowany 2-3 razy w tygodniu przez 4-16 tygodni, a czas trwania sesji wynosił od 40-60 min.

\section{Słowa kluczowe}

funkcjonowanie, osoby starsze, metoda Pilatesa, gerontoprofilaktyka 


\section{INTRODUCTION}

It is known that regular physical activity is beneficial at every stage of human life, including older adulthood. It is proven that it reduces the risk of disorders such as breast and colon cancer, cardiovascular diseases and motor disability[1-4]. Regular exercises are also essential for preventing diabetes as they improve glucose tolerance and insulin sensitivity [5]. They also increases better physical and mental functioning crucial aspects for improving the quality of independent life [6]. Physical inactivity is a risk factor which may lead to earlier death [7]. With ageing, the risk of falling is even greater [8]. Balance and risk of falling are the most common problems affecting seniors. Ostrowska et al. [8] pointed out that up to $50 \%$ of the elderly who live in their own homes and $80 \%$ of those who live in nursing homes complained about problems with balance. Fear of falling is another issue which causes more physical inactivity and might lead to worsened mental capabilities, as well as depression.

The World Health Organization (WHO) prepared recommendations for the physical activity of people over the age of 65 which advised spending at least 150 minutes on moderate-intensity physical activity per week, or 75 minutes of intensive physical activity per week, or a combination of moderate and vigorous physical activity [9]. A single aerobic workout should last at least 10 minutes. A twice weekly strengthening of muscles is recommended, and for those who have problems with mobility, activities to improve balance at least three times per week $[7,9]$. When considering proper physical activity for the elderly, it is important to remember not only about the strengthening of muscles, but also to focus on correct posture, static and dynamic balance, proprioception, flexibility, and coordination. These components improve the overall performance of seniors and lead to lowered risk of falling [8]. Balance exercises should also include such components as reducing the base of support, shifting the centre of gravity, stressing postural muscle groups and reducing sensory input $[10,11]$.

\section{OBJECTIVE}

The aim of this study was to assess the current state of knowledge related to the Pilates used by older adults and to assess the actual trend with seniors in mind. In our research we took into account most recent published study included Pilates method in seniors. We focused especially on analysis of the effectiveness of Pilates exercises performed by the elderly in different aspects of human life. An attempt was also made to standardize the application of Pilates exercises for seniors.

Pilates method. Pilates is a exercising system for the improvement of postural control, flexibility and balance[12, 13]. This exercise system was developed at the beginning of the 20th century by Joseph Pilates, a German-Greek physical trainer, who named it the 'Art of Contrology', or 'Art of Self-Control'. The method consists of basic rules for proper breathing, centring, control, concentration, and fluent and precise body movement $[14,15,16]$. Centring means that each movement of the body should begin from the centre of the body. It involves adequate and synergic activation of deep trunk muscles (transversus abdominis, diaphragm abdominal oblique muscles, multifidus, pelvic floor muscles) $[15,16]$. The coordination of activity of the above-mentioned muscles is crucial for the stability of the lumbar spine. Proper breathing has a significant role during exercises for the activity of the muscles for breathing, and has to be coordinated with movements of the body $[15,16]$. Motor control is expressed by the concentration and precision of each movement the aim is to perform as perfect a movement as possible, with quality more important than quantity. Movements should be performed smoothly with flowing transitions between exercises. that stands for the rule of flow [15-17].

Pilates training concentrates on working with the emphasis on correct posture and body stabilisation, as well as mental engagement. The exercises improve muscle strength, flexibility, core stabilisation, balance, endurance and coordination $[15,16]$. Pilates exercises might be divided into two typess: activities performed on a mat where minimal equipment might be also used (e.g an elastic band or soft ball), or exercises performed on special machines like the Reformer [16, 17]. This is a specialized piece equipment consisting of a sliding horizontal platform within a box-like frame upon which a person sits, stands, kneels or reclines. Varying resistance to movement is provided via light springs attached to the moving platform and through a simple pulley system [18].

Geronto-prophylaxis, including also prevention of locomotor system disease, is an important area of aging in Western culture societies. The Pilates method, through its positive influence on the musculoskeletal system and mental health, should be promoted as a part of prohylaxis in improving and maintaining health in the elderly.

Why Pilates-based exercises may be beneficial for older adults to maintain well-being? The effectiveness of the Pilates method in seniors have been of interest in many literature reviews [12, 19-21]. All of them confirmed the beneficial role of Pilates in the improvement of balance and physical performance in seniors; however, due to the methodology of studies included in previous reviews the authors pointed out the need of carrying out studies with higher quality, bigger samples, blinded randomisations and longer follow-up.

The latest systematic review with meta-analysis by Moreno-Segura et al. [22] confirmed the results of previous research, mentioned above, concerning the influence of Pilates exercises on balance and falls in seniors. The authors searched through 612 articles published up to December 2016 and selected 15 randomized controlled trials (RCT) which were included in a systematic review. Finally, 11 of the 15 were subjected to meta-analysis. Most of the presented studies were of good quality according to the PEDro scale. Mean age of participants $-70.3 \pm 6.6$, the majority of whom were women (86.8\%). Size of the groups varied from $24-88$ subjects, time of intervention lasted between $8-12$ weeks, with a frequency of 40-60 minutes sessions, 2-3 times per week.

For the purposes of study there were used a Pilates practising mat, with or without minimal equipment, with machines or mixed equipment. In the control groups there were either no interventions (continuing daily activities) or other exercises were performed, such as yoga, traditional strength and balance training, proprioceptive neuromuscular facilitation, static stretching, or exercises on an unstable surface, or exercises on a Huber platform. According to the results of the review, Pilates is effective in improving the static, dynamic and overall state of balance in older adults, which probably 
influences the reduction of the risk of falls. Static balance is the ability to maintain postural stability and orientation with centre of mass over the base of support. Dynamic balance concerns postural stability and orientation with the centre of mass over the base of support during movement [23]. Improvement, i.e. a significant high effect, was observed in Pilates groups, compared to those with no intervention or other task-oriented training.

Meta-analysis of the RCT of Pilates mat exercises effects on physical functional performance in older adults was shown by Bueno de Souza et al. [24]. The authors searched through 518 articles published between January 2011 - March 2017 and included nine RCT in their review; however, only five of them were evaluated as high quality studies. The mean age of participants of both genders in four studies was $68.5 \pm 5.1$ years old, with females only participating in five studies. The size of groups varied from 45-88 participants. Time of intervention lasted from 4-24 week, with sessions 2-4 times per week. In all studies, each session with the Pilates mat lasting 60 minutes was analysed. It was found that Pilates mat training applied to older adults improved dynamic balance, lower limb strength hip and lower back flexibility, as well as cardiovascular endurance, ass evaluated with the 6 Minutes Walk Test. However, the authors pointed out that more high quality studies are necessary to establish 'gold standard' measurements for evaluation of the influence of Pilates on physical performance, as well as description of Pilates exercises used in interventions. In addition to the influence of Pilates on the improvement of balance, positive effects have been also noted in health perception, functionality, quality of sleep and mental state in RCT studies.

Bertoli et al. [25] investigated the influence of 6-weeks Pilates training on the functional state of senior women. The study involved 18 women divided into three equal groups, with an average age $62.68 \pm 2.34$. The intervention was carried out in each group and comprised one hour sessions performed three times a week. Pre-and post-evaluation was performed with tools like the Timed Up and Go (lower limbs agility and dynamic balance), Timed Up and Down Stairs (postural control, lower limb strength, power and range of motion, coordination), 30 second Chair Stand (lower limbs strength, power, resistance), Chair Sit and Reach (flexibility of the lumbar and hip joints) and Back Scratch (shoulder flexibility and mobility). The intervention showed significant improvement in the functional state of the evaluated women in all performed tests. It was concluded that six weeks of $\mathrm{Pi}$ lates training is adequate for improving functional capacity. Additionally, the authors advised that progression in the exercise programme should be gradual.

Curi et al. [26] evaluated life satisfaction and functional autonomy after Pilates classes in older women. The participants were 61 healthy women divided into two Pilates mat sessions twice a week for 16 weeks. No intervention was carried out in the control group (30 females, average age $63.75 \pm 0.08$ ). Outcome measurement was performed with the Riki and Jones Protocol for evaluation of functional autonomy (limbs strength, limbs flexibility, dynamic balance, aerobic endurance) and the Brazilian version of the Subjective Life Satisfaction for assessment of life satisfaction. It was found that after 16 weeks of Pilates mat training functional autonomy and life satisfaction improved significantly. The authors therefore suggest that practising Pilates might be beneficial for the healthy aging of elderly women.
Curi et al. [27] investigated the effect of Pilates on health perception and sleep quality on the same group of participants described above. The tools, like the Brazilian version of the Pittsburgh Sleep Quality Index (PSQI-BR) and General Health Questionnaire (GHQ-12) with depression and social dysfunction subscales, were used to evaluate, respectively, sleep quality and health perception. Significant improvement was observed in the intervention group in perceived health status and sleep quality. Despite the positive effects after Pilates mat sessions, the authors indicated that more studies with Pilates equipment exercises in older adults are necessary.

The latest study by Aibar-Almazan et al. [28] also concern the influence of Pilates training on sleep quality, anxiety, depression and fatigue in aq group of postmenopausal Spanish women. The research involved 110 participants with an average age of $69.15 \pm 8.94$, divided into an experimental group (55), and a control group with no physical activity (55). The time of intervention was 12 weeks with two one-hour sessions per week which included exercises performed in sitting, standing, and on the mat with minimal equipment. Evaluation was performed with outcome measures such as the Pittsburgh Sleep Quality Index (PSQI), Fatigue Severity Scale (FSS) and the Hospital Anxiety and Depression Scale (HADS). Comparing results between groups, significant improvement was found in sleep quality (duration and disturbances), depression, anxiety, and feeling of fatigue in the experimental group. However, it was recommended that evaluation of participants with sleep disorders should be performed with special measurements - actigraphy or polysomnography - rather that self-reported instruments.

Finally, Pilates sessions also influence mental abilities, such as ego-resiliency and depression, which were observed in relation to Pilates sessions by Roh [29]. The research involved 148 women with an average age of $66.3 \pm 4.29$ years who participated in a 16-week study. The intervention consisted of 50-minute sessions carried out three times per week. The Geriatric Depression Scale Short Form and Likert-scale for ego-resiliency were used for the outcome measurement. It was found that practising Pilates alleviated depression and significantly improved all components of ego-resiliency. The results of this research indicate that Pilates might be used not only to improve functional capacity, but also to deal with mental problems of the elderly, such as depression.

How should Pilates-based exercises be applied in older adults? Following the study by de Souza, it can be stated that Pilates classes can be performed safely in groups of healthy participants. Seniors should present a medical certificate allowing them to participate in the exercises, proving the absence of medical contraindications, such as orthopaedic, neurological and cardiovascular diseases, or visual disturbances [24].

As mentioned above, Pilates training in older adults can be performed on the mat or with equipment (e.g. Reformer). However, it is difficult to compare the efficacy of these two systems - there appears to be only one study concerning equipment-based Pilates in seniors [30]. The mat Pilates exercises may be easy to accept in the groups of seniors due to their low cost application, availability, and no special requirement required. The advantage of Pilates equipment training is that it is more challenging, and therefore a better stimulant for balance abilities following the recommendation of ACSM on balance exercises [11]. On the other hand, the 
application of Pilates with equipment (e.g. Reformer) may be limited due to additional cost and organization, as well as personal prejudices linked to the usage of equipment.

For the better improvement of dynamic balance training, it should be performed in a more challenging position, e.g. standing up. The Pilates mat programme should also comprise balance exercises [24].

On the basis of literature, it can be assumed that Pilates training in the group of older adults should include a 1-10 set of 3-10 repetitions (depending on the exercises) in three phases of each session (warm-up, main and cool-down, with stretching and relaxation) [25-26, 28-29]. It might be also stated that the level of exercises should increase gradually, from beginners to intermediates [25].

Goedert et al. [31] investigated the optimal dose for improving balance abilities in seniors. The authors looked through 762 articles published between 2006 - March 2017. After selection, 15 publications were included in their review (10 RCT, four quasi-experimental studies and one cross-over study). Mean age of participants $-70.35 \pm 2.85$; size of the study groups varied - 8-64 participants). Each Pilates session, on the mat, with apparatus or mixed Pilates, lasted at least 40 minutes and performed two or three times a week, with the time of the intervention from 4-12 weeks. The authors concluded that Pilates with machines or mixed Pilates should be practised at least twice a week, but three times a week when performed only on a Pilates mat. Additionally, each session should last for a minimum of 40 minutes, and the intervention should be continued for at least five weeks when Pilates is performed twice a week. Alternatively, there should be minimum of 12 sessions when Pilatres is practised three times a week for four 4 weeks. According to the authors, in order to gain better balance abilities, it is necessary to use the recommended dose of Pilates sessions mentioned above. It should be also emphasized that Pilates sessions in older adults should be supervised by qualified instructors [22].

\section{CONCLUSIONS}

Pilates is a safe training recommended for seniors by many authors. It has been proved that the exercises improve not only the components of the functional state, such as balance, flexibility or muscle strength, but also influences on the quality of life, better mood, sleep quality or decreases symptoms of depression in seniors.

However, there is lack of methodological 'gold standards' for Pilates sessions in their application to seniors. Only one presented study by Goedert et al. provides recommended doses of Pilates exercises when considering improvement in the balance abilities in seniors. Thee authors recommend practising Pilates three times a week when performing only Pilates mat exercises, and twice a week when performing then exercises with machines or in mixed exercises. In most publications, this kind of training is performed two or three times a week in which a single session lasted 40-60 minutes, which seems to be the proper dose of Pilates for older adults. However, the time of the intervention varied from 4 to 12 weeks.

Many differences have been observed between Pilates sessions as a result of some exercises having been performed on mats, some with minimal equipment, and others using machines, or mixed exercises. This is the reason that more studies are necessary in which different type of Pilates sessions might be compared with each other, as well as compared with other kinds of training or activities in senior male and female participants.

To sum up, Pilates training may be considered as a recommended form of physical activity in older adults for improving their physical performance and mental well-being.

\section{REFERENCES}

1. Morris JS, Bradbury KE, Cross AJ, Gunter MJ, Murphy N. Physical activity, sedentary behaviour and colorectal cancer risk in the UK Biobank. Br J Cancer. 2018; 118(6): 920-929. doi:10.1038/bjc.2017.496

2. Lynch BM, Neilson HK, Friedenreich CM. Physical activity and breast cancer prevention. Recent Results Cancer Res. 2011; 186: 13-42. doi: 10.1007/978-3-642-04231-7_2

3. Lachman S, Boekholdt SM, Luben RN, Sharp SJ, Brage S, Khaw KT, Peters RJ, Wareham NJ. Impact of physical activity on the risk of cardiovascular disease in middle-aged and older adults: EPIC Norfolk prospective population study. Eur J Prev Cardiol. 2018; 25: 200-208. $10.1177 / 2047487317737628$

4. Fielding RA, Guralnik JM, King AC, Pahor M, McDermott MM, Tudor-Locke C, Manini TM, Glynn NW, Marsh AP, Axtell RS, et al. Dose of physical activity, physical functioning and disability risk in mobility-limited older adults: Results from the LIFE study randomized trial. PLoS One 2017; 12: e0182155. doi: 10.1371/journal.pone.0182155

5. Galaviz KI, Narayan KMV, Lobelo F, Weber MB. Lifestyle and the Prevention of Type 2 Diabetes: A Status Report. Am J Lifestyle Med. 2015; 12(1): 4-20. doi:10.1177/1559827615619159

6. Bennett JA, Winters-Stone K. Motivating older adults to exercise: what works? Age Ageing 2011; 40: 148-149. doi: 10.1093/ageing/afq182

7. Taylor D. Physical activity is medicine for older adults. Postgrad Med J. 2014; 90: 26-32. doi: 10.1136/postgradmedj-2012-131366

8. Ostrowska B, Giemza CZ, Demczuk-Włodarczyk E, Adamska M. Evaluation of balance and gait in the elderly residents of nursing home. Physiotheraphy 2010; 18: 40-48. doi: 10.2478/v10109-010-0077-9

9. World Health Organization. Global Recommendations on Physical Activity for Health. http://www.who.int/dietphysicalactivity/factsheet_olderadults/en/ (access: 10.07.2019)

10. Sherrington C, Tiedemann A, Fairhall N, Close JC, Lord SR. Exercise to prevent falls in older adults: an updated meta-analysis and best practice recommendations. N S W Public Health Bull. 2011; 22: 78-83. doi: $10.1071 / \mathrm{NB} 10056$

11. Chodzko-Zajko WJ, Proctor DN, Fiatarone Singh MA, Minson CT, Nigg CR, Salem GJ, Skinner JS, Medicine ACoS. American College of Sports Medicine position stand. Exercise and physical activity for older adults. Med Sci Sports Exerc. 2009; 41: 1510-1530.

12. de Oliveira FC, de Almeida Fagundes A, Gorges B. Effects of Pilates method in elderly people: Systematic review of randomized controlled trials. J Bodyw Mov Ther. 2015; 19: 500-508. doi: 10.1016/j. jbmt.2015.03.003

13. de Oliveira LC, Gonçalves de Oliveira R, Pires-Oliveira DA. Effects of Pilates on muscle strength, postural balance and quality of life of older adults: a randomized, controlled, clinical trial. J Phys Ther Sci. 2015; 27: 871-876. doi: 10.1589/jpts.27.871

14. Latey P.The Pilates method: history and philosophy. Journal of Bodywork and Movement Therapies 2001; 5: 275-282. doi: 10.1054/jbmt.2001.0237

15. Muscolino JE, Cipriani S. Pilates and the "powerhouse"-I. Journal of Bodywork and Movement Therapies 2004; 8: 15-24. doi: 10.1016/ S1360-8592(03)00057-3

16. Wells C, Kolt GS, Bialocerkowski A. Defining Pilates exercise: a systematic review. Complement Ther Med. 2012; 20: 253-262. doi: 10.1016/j. ctim.2012.02.005

17. Di Lorenzo CE. Pilates: what is it? Should it be used in rehabilitation? Sports Health 2011; 3(4): 352-361. doi:10.1177/1941738111410285

18. Sorosky S, Stilp S, Akuthota V. Yoga and pilates in the management of low back pain. Curr Rev Musculoskelet Med. 2008; 1(1): 39-47. doi:10.1007/s12178-007-9004-1

19. Barker AL, Bird ML, Talevski J. Effect of pilates exercise for improving balance in older adults: a systematic review with meta-analysis. Arch Phys Med Rehabil. 2015; 96 (4): 715-723. doi: 10.1016/j.apmr.2014.11.021 20. Bullo V, Bergamin M, Gobbo S, Sieverdes JC, Zaccaria M, Neunhaeuserer D, Ermolao A. The effects of Pilates exercise training on 
physical fitness and wellbeing in the elderly: A systematic review for future exercise prescription. Prev Med. 2015; 75: 1-11. doi: 10.1016/j. ypmed.2015.03.002

21. Engers PB, Rombaldi AJ, Portella EG, Silva MC. The effects of the Pilates method in the elderly: a systematic review. Rev Bras Reumatol Engl Ed. 2016; 56(4): 352-365. doi: 10.1016/j.rbre.2016.05.005

22. Moreno-Segura N, Igual-Camacho C, Ballester-Gil Y, Blasco-Igual MC, Blasco JM. The Effects of the Pilates Training Method on Balance and Falls of Older Adults: A Systematic Review and Meta-Analysis of Randomized Controlled Trials. J Aging Phys Act. 2018; 26: 327-344. doi: 10.1123/japa.2017-0078

23. Karimi MT, Solomonidis S. The relationship between parameters of static and dynamic stability tests. J Res Med Sci. 2011; 16(4): 530-535.

24. Bueno de Souza RO, Marcon LF, Arruda ASF, Pontes Junior FL, Melo RC. Effects of Mat Pilates on Physical Functional Performance of Older Adults: A Meta-analysis of Randomized Controlled Trials. Am J Phys Med Rehabil. 2018; 97: 414-425. doi: 10.1097/PHM.0000000000000883

25. Bertoli J, Biduski GM, de la Rocha Freitas C. Six weeks of Mat Pilates training are enough to improve functional capacity in elderly women J Bodyw Mov Ther. 2017; 21: 1003-1008. doi: 10.1016/j.jbmt.2016.12.001
26. Curi VS, Haas AN, Alves-Vilaça J, Fernandes HM. Effects of 16-weeks of Pilates on functional autonomy and life satisfaction among elderly women. J Bodyw Mov Ther. 2018; 22: 424-429.

27. Curi VS, Vilaça J, Haas AN, Fernandes HM. Effects of 16-weeks of Pilates on health perception and sleep quality among elderly women. Arch Gerontol Geriatr. 2018; 74: 118-122.

28. Aibar-Almazán A, Hita-Contreras F, Cruz-Díaz D, de la Torre-Cruz M, Jiménez-García JD, Martínez-Amat A. Effects of Pilates training on sleep quality, anxiety, depression and fatigue in postmenopausal women: A randomized controlled trial. Maturitas. 2019; 124: 62-67. https://doi.org/10.1016/j.maturitas.2019.03.019

29. Roh SY. Effect of a 16-week Pilates exercise program on the ego resiliency and depression in elderly women. J Exerc Rehabil. 2016; 12(5): 494-498. doi: $10.12965 /$ jer. 1632704.352

30. Roller M, Kachingwe A, Beling J, Ickes DM, Cabot A, Shrier G. Pilates Reformer exercises for fall risk reduction in older adults: A randomized controlled trial. J Bodyw Mov Ther. 2018; 22(4): 983-998. doi: 10.1016/j. jbmt.2017.09.004

31. Goedert A, Santos KB, Bento PCB, Rodacki ALF. The effect of pilates practice on balance in elderly: a systematic review. Rev Bras Ati Fis Saúde. 2018; 23: e0019. doi: 10.12820/rbafs.23e0019 